\title{
Wastewater Treatment of Mariout Lake Drains Using Combined Physical, Chemical, and Biological Methods in Microcosm Experiments
}

\author{
Hermine RZ Tadros \\ Professor and Head of Marine Chemistry, Marine Chemistry Department, Marine \\ Environment Division, National Institute of Oceanography \& Fisheries, Qayet Bay, \\ Alexandria, Egypt \\ Samia Kh Hamdona \\ Professor of Marine Chemistry, Marine Chemistry Department, Marine Environment \\ Division, National Institute of Oceanography \& Fisheries, Qayet Bay, Alexandria, Egypt \\ Mary G Ghobrial \\ Professor of Aquatic Plants, Hydrobiology Department, Marine Environment Division, \\ National Institute of Oceanography \& Fisheries, Qayet Bay, Alexandria, Egypt \\ Email: mary_ghobrial@ hotmail.com (Corresponding Author) \\ Mona F El-Naggar \\ Lecturer of Marine Chemistry, Marine Chemistry Department, Marine Environment Division, \\ National Institute of Oceanography \& Fisheries, Qayet Bay, Alexandria, Egypt \\ Omayma H Abd El-Hamid
}

Lecturer of Marine Chemistry, Marine Chemistry Department, Marine Environment Division, National Institute of Oceanography \& Fisheries, Qayet Bay, Alexandria, Egypt

Received: April 11, 2019 Accepted: June 2, 2019 Published: June 3, 2019

doi:10.5296/ast.v7i2.14651 URL: https://doi.org/10.5296/ast.v7i2.14651

\begin{abstract}
The treatment of wastewater is a must due to the decrease of clean water and the increase in the consumption of fresh water for domestic uses. This study discusses the physical, chemical, and biological treatments of water from different types of Mariout Lake drains. It also aims at a designation of appropriate wastewater treatment process for sewage water (El-Qalah drain), agriculture water (El-Umoum drain), and raw drinking water before treatment (Nubareya canal) so as to adopt an appropriate procedure to be applied as the drains discharge their wastewaters
\end{abstract}


in Mariout Lake affecting its water quality as well as its fish productivity. Obtaining secure effluents for discharge in natural water bodies (El-Mex bay), or using treated effluents in agriculture or industrial purposes, is a target too, open for estimation. Alum, aeration beside two natural medicinal plants, piper nigrum (Black Pepper) and dry ginger (Zingiber officinalis), and the eukaryotic microorganism yeast, were used for treatment, in addition to the freshwater submerged macrophyte Ceratophyllum demersum.

The results of the physicochemical parameters revealed that the best material for treatment in El-Qalaa sewage drain was by Alum + Aeration + Ginger + Ceratophylum demersum.

The most preferable material for both the raw drinking water of Nubareya canal and El-Umoum agricultural wastewater was Alum + Aeration + Yeast + Ceratophylum demersum.

Regarding the four trace metals' $(\mathrm{Zn}, \mathrm{Pb}, \mathrm{Fe}$, and $\mathrm{Cu})$ concentration treatments, the best treatment in all cases was found to be Alum + Aeration + Yeast + Ceratophylum demersum, except for $\mathrm{Zn}$ in El-Qalaa sewage water which had to be treated by Alum + Aeration + Ginger + Ceratophylum demersum.

Keywords: sewage water, agricultural water, raw drinking water, treatment, Alum; Aeration, piper nigrum, ginger, yeast, Ceratophylum demersum

\section{Introduction}

Egypt has been listed among the top ten countries threatened with water scarcity by the year 2025 due to the rapidly increasing population. Such a situation of water shortage necessitates seeking new water supplies for agricultural activities, which consume about $86.3 \%$ of the water supply in Egypt (Abdel-Shafy and Raouf, 2002). Using waste water for irrigation purposes was one of the available alternatives that can be adopted. In this context, transitional water bodies in the country gain special relevance. Lake Mariout, for a long time, has been a source of fish production in Egypt. Nowadays, some parts of it are used in aquacultural activities. It became one of the most heavily populated urban areas in Egypt, and the Lake has been subjected to various anthropogenic activities (Mateo, 2009; Saad et al., 2017). Lake Mariout not only represents a possible future reservoir of treated waste waters, but could also become a much more important source of fish than it is today, a unique area for leisure, and a priceless natural environment for future generations to learn the importance of staying connected to nature.

The discharge of wastewater directly into water bodies resulted in a significant deterioration of water quality of such bodies. In addition, untreated wastewater (sewage), containing a large amount of organic matter, discharged into a river/stream will consume the dissolved oxygen needed to meet the biochemical oxygen demand (BOD) of wastewater, thus depleting the dissolved oxygen of the stream, and thereby causing fish to die, and other undesirable effects. Moreover, heavy metals pollution is one of the most relevant environmental problems nowadays (Bhatti \& Latif, 2011).

Methods of wastewater treatment were first developed in response to the adverse conditions caused by the discharge of wastewater to the environment and the concern for public health. 
Also, as populations grew, the quantity of wastewater generated rose rapidly and the deteriorating quality of this huge amount of wastewater exceeded the self-purification capacity of the streams and river bodies (Gray, 1989).

Wastewater treatment is a process used to convert wastewater into an effluent that can be returned to the water cycle with minimum impact on the environment, or directly reused (Zhou \& Smith, 2002). Wastewater treatment involves the breakdown of complex organic compounds in wastewater into simpler compounds that are stable and nuisance-free, either physico-chemically and/or by using micro-organisms (biological treatment) (Grady et al., 1999 \& Rehm \& Reed 1986).

Studies on the treatment of effluent bearing heavy metals have revealed adsorption to be a highly effective technique. Chang Pan et al., (2018) suggested heavy metals remediation including physical, chemical, and bioremediation techniques, as well as joint techniques.

Adsorption involves the removal of specific compounds from wastewater on solid surfaces using the forces of attraction between bodies. Alum is mainly used in water treatment processes for the removal of suspended matters (Lai et al., 2015).

Based upon the reviewed literature (Lynette et al., 2007), several hypotheses can be generated regarding the use of alum in wetlands. First, it appears that alum will effectively sequester $\mathrm{P}$ in a municipal wastewater treatment wetland. Moreover, changes in the soil mineralogy will be evident due to the addition of alum. The author utilized both laboratory scale and field scale experiments.

On the other hand, medicinal plants such as dry ginger (Zingiber officinalis) and black pepper (Piper nigrum) have been used for the adsorption of heavy metals from the water samples (Juliana et al., 2016). Such absorbents also have an advantage of being a low cost material, user friendly, and locally available.

In the early 1990s, the Japanese Research Institute discovered the application of yeast wastewater treatment technology for the first time in the world (Yan Wang et al., 2018). Because of its fast growth and high metabolic efficiency, it has attracted much attention. The process of seeding inoculation of microorganisms, such as yeast (fungus), for degrading organic materials in wastewater treatment has rapidly become an increasing practice in many countries because it is economical and its application is uncomplicated.

Yeast, as a very valuable microbial resource, has a good enzyme system in the body and can adapt to a variety of special environments. Therefore, it plays an important role in the biological treatment of wastewater. The application of yeast in the field of wastewater treatment such as high concentration organic wastewater, heavy metal ion wastewater, and domestic sewage were investigated by Yan Wang et al., (2018). However, Karla et al., (2013) investigated the biosorption of zinc $(\mathrm{Zn})$, copper $(\mathrm{Cu})$, manganese $(\mathrm{Mn})$, and iron $(\mathrm{Fe})$ with immobilized yeast spp. Yeast can convert most of the organic matter into non-toxic, nutritious single cell protein, which is highly efficient with regards to wastewater treatment (Yang \& Zheng, 2014).

Biological treatment is used primarily to remove the biodegradable organic substances (colloidal 


\section{Macrothink}

or dissolved) in wastewater. Plants can be used as low-cost extraction devices to purify polluted water. Biological remediation is perhaps the most important mechanism in removing pollutants in constructed wetlands. Wetland plants are widely recognized for their ability to capture and remove contaminants, particularly since some of the pollutants are essential nutrients, such as nitrate, ammonium, and phosphate which are easily taken up in such plants.

One of the economic and rapid methods for element removal is displacement of metals by biosorption (Foroughi et al., 2010); therefore they concluded that the coontail Ceratopyllum demersum can be used for refining wastewater. Bo Jiang et al., (2018) evaluated the behavior of heavy metal uptake by 12 native aquatic macrophytes, including $C$. demersum, and found accumulation ability and high uptake capacity potential.

This research aims to designation of appropriate wastewater treatment process for sewage water (El-Qalah drain), agriculture water (El-Umoum drain), and raw drinking water before treatment (Nubareya canal) in order to adopt an appropriate treatment method to be applied. Obtaining secure effluents for discharge in natural water bodies (El-Mex bay), or using treated effluents in agriculture or industrial purposes is a target too, open to estimation.

\section{Materials and Methods}

\subsection{Sampling Collection}

Wastewater samples were collected from two main drains, and raw drinking water from a canal (El-Qalaa, El-Umoum and Nubareya). Each sample was collected in 20L polyethylene plastic bottle during spring. These different types of water are considered the main inflows to Lake Mariout (Fig. 1).

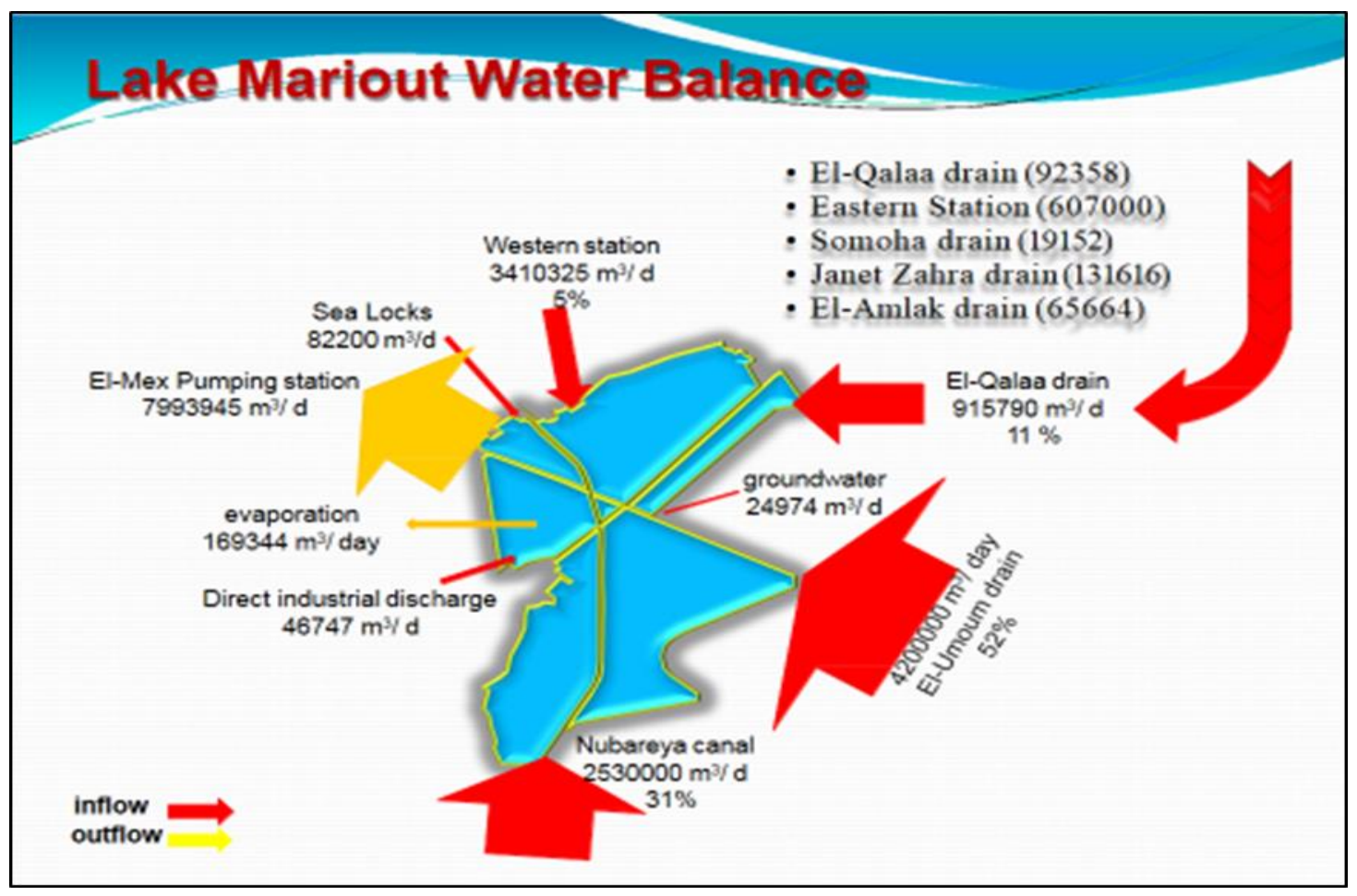

Figure 1. The three main wastewater drains inflow sources in Lake Mariout 


\subsection{Preparation and Treatment of Samples}

Alum adsorption tests were performed in a batch of polyethylene bottles containing collected wastewater samples. Twenty gram Alum $\left(\mathrm{Al}_{2} \mathrm{O}_{3}\right)$ (corundum) were added to $20 \mathrm{~L}$ of drain wastewater. The $\mathrm{pH}$ was adjusted to 7.5 and left for sedimentation. After filtration, ventilation began by pumping, followed by addition and integration of different biological materials (natural plants) with or without a macrophyte for treatment, and all were accompanied by aeration. The experiment was established in microcosm glass basins $(5 \mathrm{~L})$.

Two natural medicinal plants, piper nigrum ((Black Pepper) and dry ginger (Zingiber officinalis), and the eukaryotic microorganism yeast were used for treatment, in addition to the freshwater submerged macrophyte Ceratophyllum demersum. 0.2, 0.4, 0.8 and $1.0 \mathrm{~g} / 100$ $\mathrm{ml}$ wastewater of the biosorbent mentioned before, respectively, while $5 \mathrm{~g} / \mathrm{L}$ of the macrophyte were used. The key for treatment was as follows: I. Drain water before treatment, II. Drain water (Alum + Aeration), III. Drain water (Alum + Aeration) + 5g/l Ceratophylum, IV. Drain water (Alum + Aeration) $+10 \mathrm{~g} / \mathrm{l}$ piper nigrum, V. Drain water (Alum + Aeration) $+10 \mathrm{~g} / \mathrm{l}$ piper nigrum $+5 \mathrm{~g} / \mathrm{l}$ Ceratophylum, VI. Drain water (Alum + Aeration) $+10 \mathrm{~g} / \mathrm{l}$ ginger, VII. Drain water (Alum + Aeration) $+10 \mathrm{~g} / \mathrm{l}$ ginger $+5 \mathrm{~g} / \mathrm{l}$ Ceratophylum, VIII. Drain water $($ Alum + Aeration $)+10 \mathrm{~g} / \mathrm{l}$ yeast, and IX. Drain water (Alum + Aeration $)+10 \mathrm{~g} / \mathrm{l}$ yeast $+5 \mathrm{~g} / \mathrm{l}$ Ceratophylum all at $24 \mathrm{~h}$.

Treated water samples were tested at 15, 30, 60, 90, 120 min intervals, and overnight, during the biosorption experiments and analyzed for oxidizable organic matter (OOM), nitrite, nitrate, phosphate, silicate, and sulphate. Three sets of experiments for treatment of El-Qalaa, El-Umoum, and Nubareya polluted wastewater sources were carried out in duplicate, in spring season.

\subsection{Determination of the Chemical Parameters}

Oxidizable organic matter (OOM) was determined using permanganate values test (FAO, 1975). The nutrients parameters, nitrite, nitrate, phosphate, and silicate were determined colourimetrically according to the methods described by APHA (1995). The sulphate was measured turbidimetrically using a spectrophotometer at wave length 420nm (Rossum \& Villarruz, 1961).

\subsection{Determination of the Heavy Metals}

Water samples were digested according to the method described in APHA (1995). The levels of iron $(\mathrm{Fe})$, copper $(\mathrm{Cu})$, zinc $(\mathrm{Zn})$, and lead $(\mathrm{Pb})$ in digests of water were determined using atomic absorption spectrophotometer model (SHIMADZU-AA-6800) equipped with different cathode lamps with air acetylene flame atomic absorption (FAA) technology (Thermal atomization) for $\mathrm{Fe}, \mathrm{Cu}, \mathrm{Zn}$, and $\mathrm{Pb}$ at specific wavelengths appropriate for each metal.

\section{Results}

A study on the physicochemical parameters on Lake Mariout during 2014 showed that the range of some physicochemical parameters were $18-27.5^{\circ} \mathrm{C}$ for Temperature; $0.28-7.40 \%$ o for Salinity; $7.84-8.84$ for $\mathrm{pH}$; $0.60-5.24 \mathrm{meq} / \mathrm{l}$ for Total alkalinity; $0.14-10.71 \mathrm{mg} / \mathrm{l}$ for DO; 


\section{MInstitute Macrothink $_{\text {Int }}$}

3.2-134.4mg/1 for OOM. The results of nutrient salts range $(\mu \mathrm{M})$ were from 0.05 to 22.48 for Nitrite; from 0.14 to 66.67 for Nitrate; from 0.39 to 157.26 for ammonia; from 0.10 to 45.30

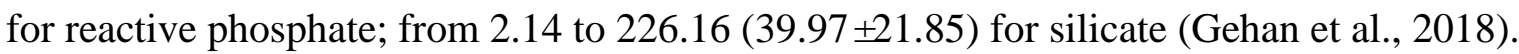

There is a continuous need to identify and develop an efficient, low cost adsorbent for facile, and an efficient removal process. Adsorption on low cost materials such as biomass has been performed by contemporary researchers and was found to be effective (Juliana, 2016), (Akar et al., 2009), (Orumwense, 1996). They are simple to handle and have a very low maintenance cost (Dubey \& Gopal, 2007).

Alum has been used for phosphorus inactivation in lakes and for phosphorus removal in wastewater treatment plants for decades (Welch \& Schrieve, 1994, Berkowitz et al., 2006). In the present research, alum and aeration considerably lowered $\mathrm{OOM}$ and $\mathrm{SO}_{4}{ }^{2-}$, while other nutrient loads decreased slightly, particularly $\mathrm{PO}_{4}{ }^{3-}$ compared with Lynette results. The effect of combined physical, chemical, and biological treatments on the chemical parameters of the wastewater for El-Qalaa drain, El-Umoum drain, and Nubareya canal were studied as follows:

\subsection{El-Qalaa Drain}

3.1.1 The Effect of Different Treatments on the Chemical Parameters of the Sewage Wastewater of El-Qalaa Drain

Table (1) presents the oxidizable organic matter $(\mathrm{OOM})$ recorded $34.8 \mathrm{mg} \mathrm{O}_{2} / \mathrm{l}$ at Qalah before treatment. After treatment, the OOM fluctuated between $8.44 \mathrm{mg} \mathrm{O}_{2} / 1$ for the treatment by $[\mathrm{II}]$ and $2.56 \mathrm{mgO}_{2} / 1$ for $[\mathrm{VII}]$ treatment. Phosphate concentration $\left(\mathrm{PO}_{4}{ }^{3-}\right)$ recorded $16.4 \mu \mathrm{M}$ before treatment and fluctuated between $15.9 \mu \mathrm{M}$ for the treatment by [1I] and $3.05 \mu \mathrm{M}$ for [VIII] treatment, while silicate recorded $89.49 \mu \mathrm{M}$ before treatment and variation from $63.73 \mu \mathrm{M}$ for the treatment by [II] and $15.41 \mu \mathrm{M}$ for [VI] treatment. Nitrite recorded $2.25 \mu \mathrm{M}$ before treatment and variations from $1.13 \mu \mathrm{M}$ for the treatment by [II] to $0.15 \mu \mathrm{M}$ for [VII] treatment. Nitrate value recorded $5.33 \mu \mathrm{M}$ before treatment and fluctuated between $4.67 \mu \mathrm{M}$ for the treatment by [V] and $0.2 \mu \mathrm{M}$ for [VIII] treatment. Sulphate $\left(\mathrm{SO}_{4}{ }^{--}\right)$recorded $3.49 \mathrm{~g} / \mathrm{l}$ before treatment and differed between $2.36 \mathrm{~g} / \mathrm{l}$ at the treatment by [II] and $1.31 \mathrm{~g} / \mathrm{l}$ for [IX] treatment.

It is noticed from the results shown in Table (1) and Fig. (2) that studies of the chemical parameters of El-Qalaa drain wastewater showed reduced concentrations of oxidizable organic matters and nutrient loads $\left(\mathrm{PO}_{4}{ }^{3-}, \mathrm{SiO}_{3}{ }^{-}, \mathrm{NO}_{2}{ }^{-}\right.$, and $\left.\mathrm{NO}_{3}{ }^{-}\right)$beside $\mathrm{SO}_{4}{ }^{2-}$ after treatments. Afterwards, they were considerably reduced after using biological materials, with maximum reduction in ginger and the macrophyte Ceratophylum demersum integrated medium, recording nearly minimum concentrations of most parameters. 
Table 1. The effect of different treatments on some chemical parameters in El-Qalaa Drain wastewater during spring 2014

\begin{tabular}{|c|c|c|c|c|c|c|}
\hline El-Qalaa & $\mathrm{OOM} \mathrm{mgO}_{2} / \mathrm{l}$ & $\mathrm{PO}_{4}{ }^{3-} \mu \mathrm{M}$ & $\mathrm{SiO}_{3}^{-} \mu \mathrm{M}$ & $\mathrm{NO}_{2}^{-} \mu \mathrm{M}$ & $\mathrm{NO}_{3}{ }^{-} \mu \mathrm{M}$ & $\mathrm{SO}_{4}{ }^{2-} \mathrm{g} / \mathrm{l}$ \\
\hline $\begin{array}{l}\text { I. El-Qalaa } \\
\text { sewage }\end{array}$ & 34.8 & 16.4 & 89.49 & 2.25 & 5.33 & 3.49 \\
\hline $\begin{array}{l}\text { II. El-Qalaa } \\
\text { sewage }+ \text { Alum + } \\
\text { aeration }\end{array}$ & 8.44 & 15.9 & 63.73 & 1.13 & 4.25 & 2.36 \\
\hline $\begin{array}{l}\text { III. El-Qalaa } \\
\text { sewage }+ \text { Alum }+ \\
\text { aeration }+ \\
\text { Ceratophyllum }\end{array}$ & 5.76 & 10.3 & 29.99 & 0.62 & 4.24 & 2.34 \\
\hline $\begin{array}{l}\text { IV. El-Qalaa } \\
\text { sewage }+ \text { Alum + } \\
\text { aeration }+ \text { Piper } \\
\text { nigrum }\end{array}$ & 5.12 & 8.05 & 62.89 & 0.45 & 4.23 & 2.35 \\
\hline $\begin{array}{l}\text { V. El-Qalaa } \\
\text { sewage + Piper } \\
\text { nigrum + alum + } \\
\text { aeration }+ \\
\text { Ceratophyllum }\end{array}$ & 3.52 & 7.03 & 42.48 & 0.38 & 4.67 & 2.31 \\
\hline $\begin{array}{l}\text { VI. El-Qalaa } \\
\text { sewage + Ginger } \\
+ \text { alum + aeration }\end{array}$ & 3.2 & 3.15 & 15.41 & 0.68 & 4.25 & 2.31 \\
\hline $\begin{array}{l}\text { VII. El-Qalaa } \\
\text { sewage + Ginger } \\
+ \text { alum + aeration } \\
+ \text { Ceratophyllum }\end{array}$ & 2.56 & 3.9 & 17.07 & 0.15 & 2.04 & 2.12 \\
\hline $\begin{array}{l}\text { VIII. El-Qalaa } \\
\text { sewage + Yeast + } \\
\text { alum + aeration }\end{array}$ & 5.12 & 3.05 & 28.32 & 0.93 & 0.2 & 1.32 \\
\hline $\begin{array}{l}\text { IX. El-Qalaa } \\
\text { sewage + alum + } \\
\text { aeration + Yeast + } \\
\text { Ceratophyllum }\end{array}$ & 4.16 & 3.4 & 23.74 & 0.43 & 0.24 & 1.31 \\
\hline
\end{tabular}

Treatment with yeast in the medium with alum and aeration (VIII) showed a high decrease in $\mathrm{PO}_{4}{ }^{3-}$ and $\mathrm{NO}_{3}{ }^{-}$concentrations, compared with the other treatments (Fig. 2). These results were supported by Nguyen \& Ronald, (1973), whose results indicated that high removals of phosphorus, ammonia- $\mathrm{N}$, and total $\mathrm{N}$ were achieved using yeast for treatment. Moreover, Takashi et al., (2008) suggested that yeasts would not only treat organic matter, but also remove and allow recovery of phosphorus. 


\section{Macrothink}

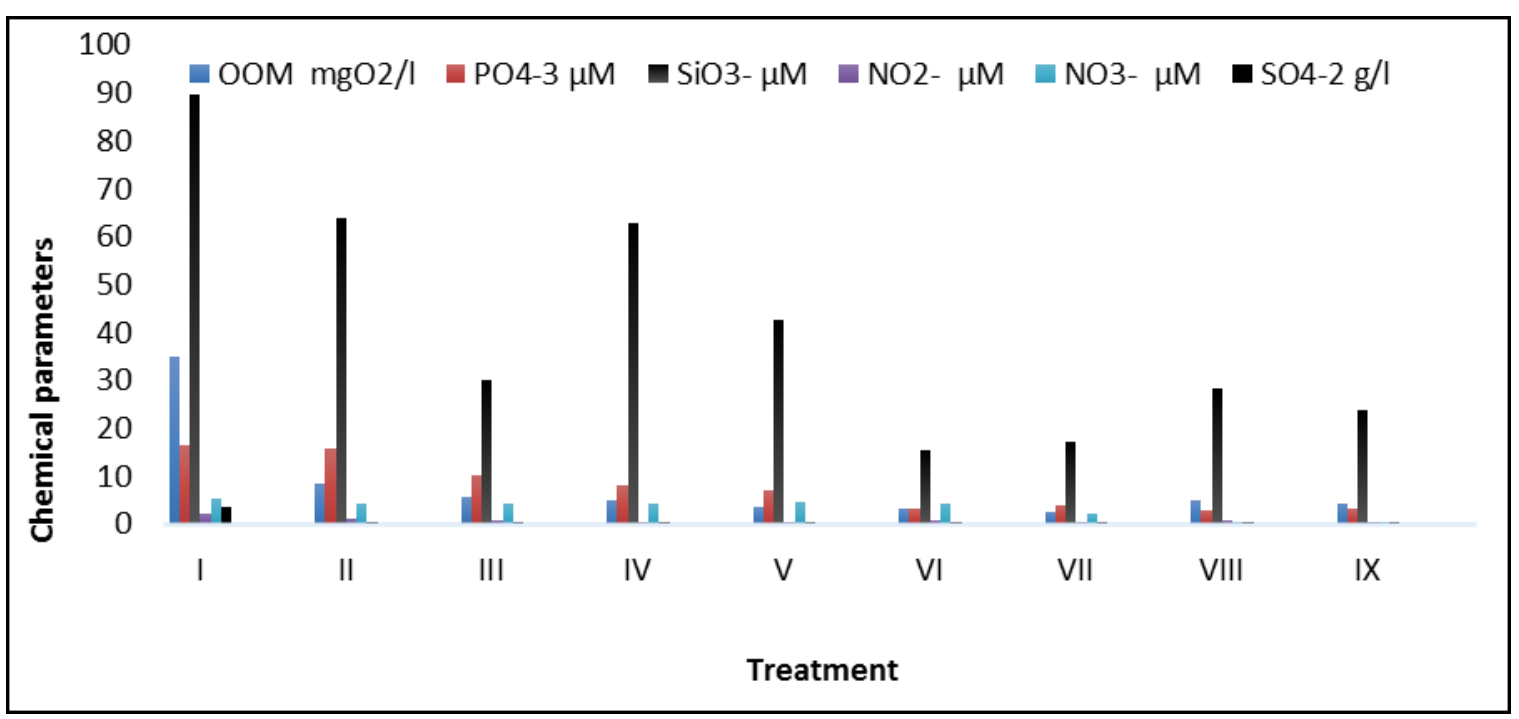

Figure 2. The effect of different treatments on the chemical parameters of El-Qalaa drain wastewater during spring 2014

3.1.2 The Effect of Different Treatments on the Trace Metals Concentrations of the Sewage Wastewater of El-Qalaa Drain

Heavy metal pollution is regarded as a severe problem because it injures the biological functions of the aquatic organisms and their accumulation in fish organs and flesh leading to serious health hazards to the consumers (Daoud et al., 1999).

Different treatments used affected the concentrations of $\mathrm{Zn}, \mathrm{Pb}, \mathrm{Fe}$, and $\mathrm{Cu}$ present in wastewater of El-Qalaa drain. Table 2 shows considerable reduction of all the four metals; Zn, $\mathrm{Pb}, \mathrm{Fe}$, and $\mathrm{Cu}$ by using piper, ginger, and yeast. On the other hand, $\mathrm{Pb}, \mathrm{Fe}$, and $\mathrm{Cu}$ recorded the least decrease in their concentrations by using Alum + Aeration + Yeast + Ceratophyllum treatment, while $\mathrm{Zn}$ recorded the least decrease in its concentration by using Alum + Aeration + Ginger + Ceratophyllum .

Treatment of heavy metal ions in wastewater and domestic sewage were investigated by Yan Wang et al., (2018). Previous authors' suggestions in both chemical and trace metals concentrations support the results of the present research, as shown in Tables 1, 2, and Figs. 2, 3. Generally, Yeast treatment medium reduced all metals under investigation.

Although reduction of pollutants under consideration was achieved in all treatment media, but were more reduced in all media with the integration of the submerged macrophyte Ceratophyllum demersum, as shown in Table 2 and Fig. 3, all pollutants were minimized. However, Foroughi et al., (2010) proved that one of the economic and rapid methods for elements removal is displacement of metals by biosorption for the purpose of purifying wastewater by Ceratophyllum demersum. Bo Jiang et al., (2018) investigated Effective phytoremediation of low-level heavy metals by native macrophytes $C$. demersum in China.

Previous studies reported that Dry Ginger (Zingiber officinalis) and Black Pepper (Piper nigrum) were used as an adsorbent for heavy metals (Remigius et al., 2003). 


\section{Macrothink}

Table 2. The effect of different treatments on the trace metals concentrations $(\mu \mathrm{M})$ of El-Qalaa Drain sewage water

\begin{tabular}{l|c|c|c|c}
\hline El-Qalaa & Zn & Pb & Fe & Cu \\
\hline (I) El-Qalaa raw sewage & 25.7 & 35 & 168 & 16 \\
\hline (II) El-Qalaa sewage +Alum + Aeration & 17.8 & 22.3 & 120.3 & 13.8 \\
\hline (IV) El-Qalaa sewage +Alum + Aeration + Piper & 16 & 19.1 & 97.4 & 10.2 \\
\hline $\begin{array}{l}\text { (V) El-Qalaa sewage +Alum + Aeration + piper } \\
+ \text { Ceratophyllum }\end{array}$ & 14.6 & 13.2 & 77.8 & 8.5 \\
\hline $\begin{array}{l}\text { (VI) El-Qalaa sewage +Alum + Aeration + } \\
\text { Ginger }\end{array}$ & 11.8 & 14.8 & 117.7 & 6.6 \\
\hline $\begin{array}{l}\text { (VII) El-Qalaa sewage +Alum + Aeration + } \\
\text { Ginger + Ceratophyllum }\end{array}$ & 9.6 & 10.3 & 103.2 & 4.8 \\
\hline $\begin{array}{l}\text { (VIII) El-Qalaa sewage +Alum + Aeration + } \\
\text { Yeast }\end{array}$ & 14.6 & 5.6 & 80.2 & 1.5 \\
\hline $\begin{array}{l}\text { (IX) El-Qalaa sewage +Alum + Aeration + Yeast } \\
+ \text { Ceratophyllum }\end{array}$ & 11.7 & 2.9 & 66.9 & 1.1 \\
\hline
\end{tabular}

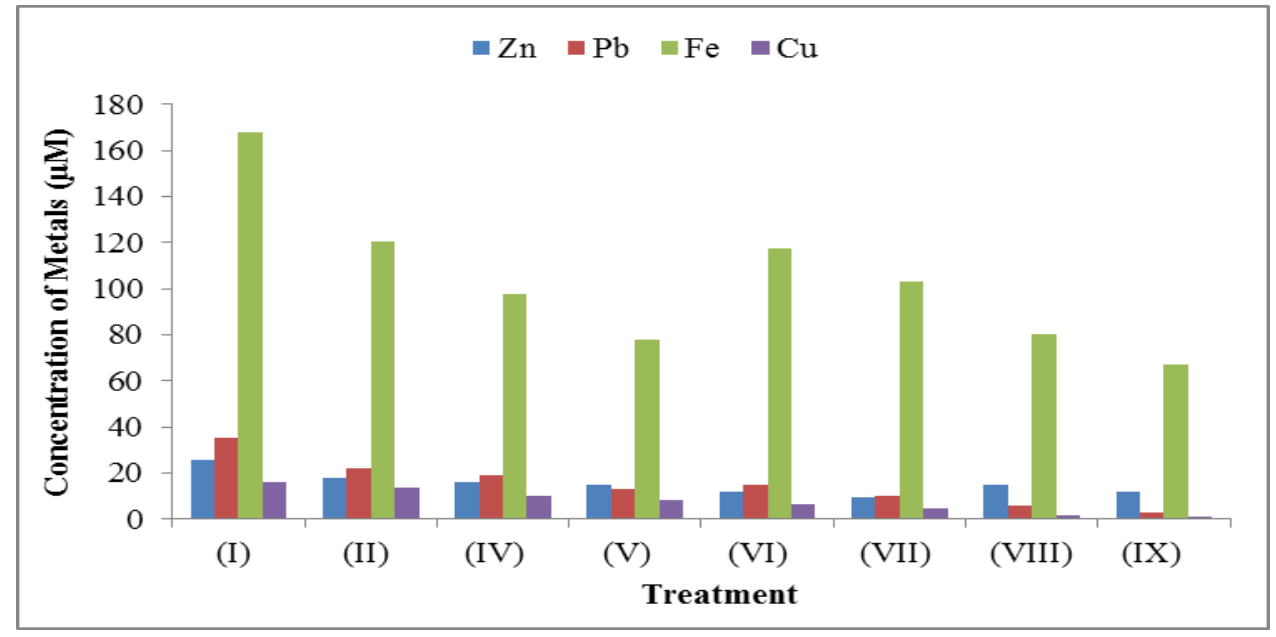

Figure 3. The effect of different treatments on the trace metals concentrations of El-Qalaa drain sewage during spring 2014

\subsection{Nubareya Canal}

It is the main source of drinking water in Alexandria City, Egypt. Nubareya's canal raw 


\section{Macrothink}

drinking water is treated before reaching houses and other domestic uses.

3.2.1 The Effect of Different Treatments on the Chemical Parameters of the Raw Drinking Water of Nubareya Canal

From Table (3) the oxidizable organic matter $(\mathrm{OOM})$ recorded $18.26 \mathrm{mgO}_{2} / \mathrm{l}$ at Nubareya before treatment (I). After treatment, (OOM) fluctuated between $13.12 \mathrm{mg} \mathrm{O}_{2} / 1$ for the treatment by (II) and $1.45 \mathrm{mgO}_{2} / \mathrm{l}$ for (IX) treatment. Phosphate concentration $\left(\mathrm{PO}_{4}{ }^{-3}\right)$ recorded $13.5 \mu \mathrm{M}$ before treatment and fluctuated between $3.14 \mu \mathrm{M}$ for the treatment by (III) and $0.35 \mu \mathrm{M}$ for (VIII) treatment. The silicate recorded $17.14 \mu \mathrm{M}$ before treatment and variation from $16.42 \mu \mathrm{M}$ for (III) and $5.53 \mu \mathrm{M}$ for (VI) treatment. Nitrite concentration recorded $0.08 \mu \mathrm{M}$ before treatment and variations from $0.08 \mu \mathrm{M}$ for the treatment by (II, III, and VII) to $0.04 \mu \mathrm{M}$ for (V) treatment. Nitrate value recorded $2.98 \mu \mathrm{M}$ before treatment and fluctuated between $2.79 \mu \mathrm{M}$ for the treatment by (III) and $1.86 \mu \mathrm{M}$ for (VIII) treatment. Sulphate $\left(\mathrm{SO}_{4}^{--}\right)$recorded $3.5 \mathrm{~g} / \mathrm{l}$ before treatment and differed between $2.51 \mathrm{~g} / \mathrm{l}$ at $(\mathrm{V})$ treatment and $1.56 \mathrm{~g} / \mathrm{l}$ for (IX) treatment.

As shown in Table 3 and Fig. 4; the best results obtained above all treatment media were observed in the alum, aeration integrated medium with yeast and also with both yeast and the macrophyte Ceratophylum demersum. Thus, $\mathrm{OOM}, \mathrm{PO}_{4}{ }^{3-}, \mathrm{SiO}_{3}{ }^{-}$, and $\mathrm{SO}_{4}{ }^{2-}$ concentrations were considerably reduced. On the other hand, alum and aeration integrated medium with both ginger and $C$. demersum recorded low values of $\mathrm{OOM}, \mathrm{PO}_{4}{ }^{3-}, \mathrm{SiO}_{3}{ }^{-}$, and $\mathrm{NO}_{2}{ }^{-}$, but to a lesser degree than the previously mentioned medium, compared with the initials (raw drinking water from Nubareya). 


\section{Ml Macrothink}

Aquatic Science and Technology

ISSN 2168-9148

2019, Vol. 7, No. 2

Table 3. The effect of different treatments on some chemical parameters in Nubareya Canal water during spring 2014

\begin{tabular}{|c|c|c|c|c|c|c|}
\hline Nubareya & $\mathrm{OOM} \mathrm{mgO}_{2} / \mathrm{l}$ & $\mathrm{PO}_{4}{ }^{3-} \mu \mathrm{M}$ & $\mathrm{SiO}_{3}{ }^{-} \mu \mathrm{M}$ & $\mathrm{NO}_{2}^{-} \mu \mathrm{M}$ & $\mathrm{NO}_{3}{ }^{-} \mu \mathrm{M}$ & $\mathrm{SO}_{4}{ }^{2-} \mathrm{g} / \mathrm{l}$ \\
\hline $\begin{array}{l}\text { I. Nubareya raw } \\
\text { water }\end{array}$ & 18.26 & 13.5 & 17.14 & 0.08 & 2.98 & 3.5 \\
\hline $\begin{array}{l}\text { II. Nubareya raw } \\
\text { water + Alum + } \\
\text { aeration }\end{array}$ & 13.12 & 3.05 & 15.41 & 0.08 & 2.07 & 2.23 \\
\hline $\begin{array}{l}\text { III. Nubareya } \\
\text { raw water + } \\
\text { Alum + aeration } \\
\text { + Ceratophyllum }\end{array}$ & 12.34 & 3.14 & 16.42 & 0.08 & 2.79 & 2.41 \\
\hline \begin{tabular}{llr} 
IV. & \multicolumn{2}{c}{ Nubareya } \\
raw water & + \\
Piper & nigrum & + \\
(alum & + \\
aeration) & + \\
\end{tabular} & 13.05 & 2.55 & 15.32 & 0.05 & 2.57 & 2.27 \\
\hline $\begin{array}{l}\text { V. Nubareya raw } \\
\text { water + Piper } \\
\text { nigrum + (alum + } \\
\text { aeration) }+ \\
\text { Ceratophyllum } \\
\end{array}$ & 12.88 & 2.2 & 10.65 & 0.04 & 2.65 & 2.51 \\
\hline $\begin{array}{l}\text { VI. Nubareya } \\
\text { raw water + } \\
\text { Ginger + (alum + } \\
\text { aeration) }\end{array}$ & 10.24 & 0.85 & 5.53 & 0.05 & 2.41 & 2.22 \\
\hline $\begin{array}{l}\text { VII. Nubareya } \\
\text { raw water + } \\
\text { Ginger + (alum + } \\
\text { aeration) + } \\
\text { Ceratophyllum }\end{array}$ & 6.08 & 0.75 & 5.69 & 0.08 & 2.7 & 2.2 \\
\hline $\begin{array}{l}\text { VIII. Nubareya } \\
\text { raw water + } \\
\text { Yeast + (alum + } \\
\text { aeration) }\end{array}$ & 1.92 & 0.35 & 8.55 & 0.05 & 1.86 & 1.94 \\
\hline $\begin{array}{ll}\text { IX. Nubareya } \\
\text { raw water }+ \\
\text { Yeast }+ \text { (alum }+ \\
\text { aeration) }+ \\
\text { Ceratophyllum }\end{array}$ & 1.45 & 0.41 & 8.52 & 0.05 & 1.95 & 1.56 \\
\hline
\end{tabular}




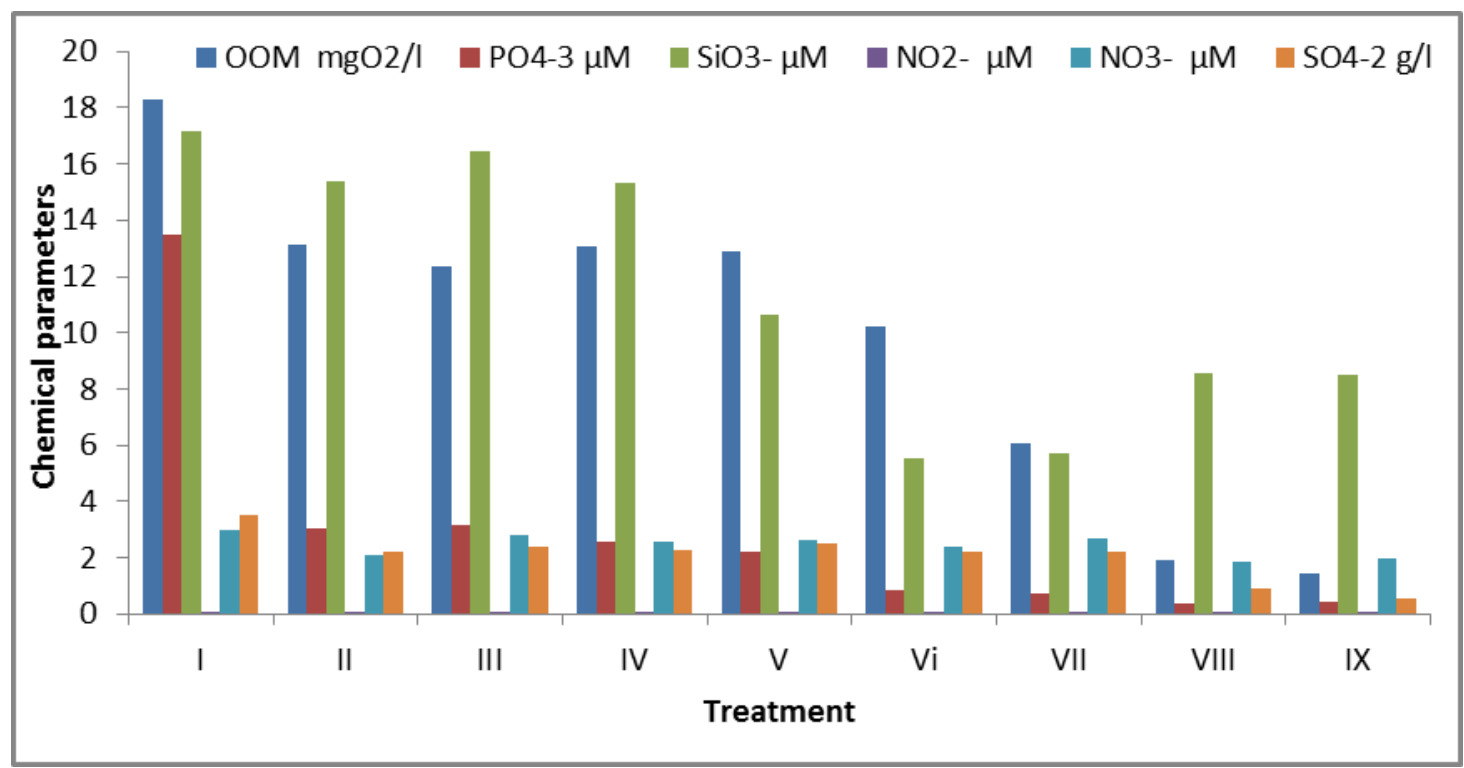

Figure 4. The effect of different treatments on the chemical parameters of Nubareya Canal water during spring 2014

3.2.2 The Effect of Different Treatments on the Trace Metals Concentrations of the Raw Drinking Water of Nubareya Canal

All treatments succeeded to reduce the concentrations of the trace metals concentrations $(\mathrm{Zn}$, $\mathrm{Pb}, \mathrm{Fe}$, and $\mathrm{Cu}$ ). The highest reduction in all trace metals concentrations was observed with the treatment by Alum + Aeration+ Yeast+ Ceratophyllum (Table 4 and Fig. 5). Besides reduction of all studied trace metals pollutants were more reduced in all media with the integration of the submerged macrophyte Ceratophyllum demersum. The treatment type most successful in reducing trace metals concentrations of Nubareya raw water was by using Yeast. Karla et al., (2013) in their studies using yeast demonstrated the biosorption capacity of heavy metals such as zinc, copper, lead, and iron. 


\section{Macrothink}

Table 4. The effect of treatments on trace metals concentrations $(\mu \mathrm{M})$ of Nubareya Canal water during spring 2014

\begin{tabular}{l|c|c|c|c}
\hline Nubareya & Zn & Pb & Fe & Cu \\
\hline (I) Nubareya raw water & 18.8 & 14.6 & 65.8 & 9.9 \\
\hline (II) Nubareya raw water + Alum + Aeration & 13.8 & 12.9 & 46.4 & 6.2 \\
\hline (IV) Nubareya raw water + Alum + Aeration +Piper & 12.8 & 8.4 & 11.5 & 5.3 \\
\hline $\begin{array}{l}\text { (V) Nubareya raw water + Alum + Aeration + piper + } \\
\text { Ceratophyllum }\end{array}$ & 10.4 & 4.8 & 9.8 & 3.9 \\
\hline $\begin{array}{l}\text { (VI) Nubareya raw water + Alum + Aeration + Ginger } \\
\text { (VII) Nubareya raw water + Alum + Aeration +Ginger+ }\end{array}$ & 8.9 & 4.7 & 21.3 & 2.8 \\
\hline Ceratophyllum & 6.9 & 23.6 & 4.2 \\
\hline $\begin{array}{l}\text { (VIII) Nubareya raw water + Alum + Aeration +Yeast } \\
\text { Ceratophyllum }\end{array}$ & 8.2 & 3.4 & 12 & 0 \\
\hline $\begin{array}{l}\text { (IX) Nubareya raw water + Alum + Aeration+ Yeast+ } \\
\text { (V) }\end{array}$ & 6.4 & 2.1 & 9.6 & 0 \\
\hline
\end{tabular}

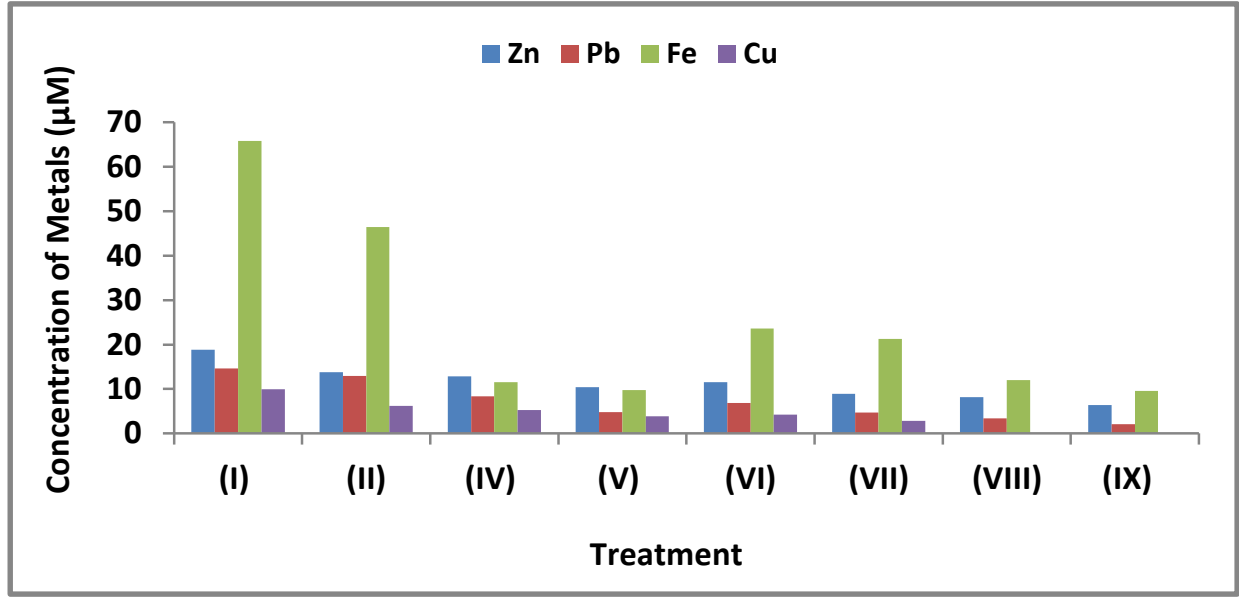

Figure 5. The effect of different treatments on the trace metals concentrations of Nubareya Canal water during spring 2014

Generally, yeast treatment showed the best results for OOM, $\mathrm{PO}_{4}{ }^{3-}, \mathrm{NO}_{2}{ }^{-}, \mathrm{NO}_{3}{ }^{-}, \mathrm{SiO}_{3}{ }^{-}$, and $\mathrm{SO}_{4}{ }^{2-}$ as well as succeeding in reducing trace metals concentrations. 


\subsection{El-Umoum Drain}

This drain is the main source of agricultural wastewater in Lake Mariout. Therefore, this study concentrates on the effect of treatments on the physicochemical parameters and trace metals concentrations in El-Umoum drain.

3.3.1 The Effect of Different Treatments on the Chemical Parameters of El-Umoum Agricultural Drain Water

From Table (5) it was noticed that the oxidizable organic matter (OOM) recorded $37.68 \mathrm{mg}$ $\mathrm{O}_{2} / \mathrm{l}$ at Umoum drain before treatment. After treatment, (OOM) fluctuated between $18.97 \mathrm{mg}$ $\mathrm{O}_{2} / 1$ for the treatment by (VIII) and $7.68 \mathrm{mgO}_{2} / 1$ for (IX) treatment. Phosphate concentration $\left(\mathrm{PO}_{4}{ }^{-3}\right)$ recorded $10.95 \mu \mathrm{M}$ before treatment and fluctuated between $9.00 \mu \mathrm{M}$ for the treatment by (II) and $1.2 \mu \mathrm{M}$ for (V, IX) treatment. The silicate recorded $88.3 \mu \mathrm{M}$ before treatment and variation from $45.82 \mu \mathrm{M}$ for the treatment by (II) and $14.16 \mu \mathrm{M}$ for (VII) treatment. Nitrite concentration recorded $33.05 \mu \mathrm{M}$ before treatment and variations from $20.18 \mu \mathrm{M}$ for the treatment by (II) to $0.1 \mu \mathrm{M}$ for (VII) treatment. Nitrate value recorded $67.13 \mu \mathrm{M}$ before treatment and fluctuated between $52.33 \mu \mathrm{M}$ for the treatment by (II) and $0.04 \mu \mathrm{M}$ for (IX) treatment. Sulphate $\left(\mathrm{SO}_{4}{ }^{--}\right)$recorded $2.45 \mathrm{~g} / \mathrm{l}$ before treatment and differed between $1.7 \mathrm{~g} / \mathrm{l}$ at the treatment by (III) and $0.78 \mathrm{~g} / \mathrm{l}$ for (IX).

As shown from Table 5 and Fig. 6, Alum + Aeration decreases the $\mathrm{OOM}, \mathrm{SiO}_{3}{ }^{-}$, and $\mathrm{SO}_{4}{ }^{2-}$ concentrations to nearly the half, and the best results obtained from all treatment media were observed in the alum, aeration integrated medium with yeast and the macrophyte Ceratophylum demersum. Thus, $\mathrm{OOM}, \mathrm{PO}_{4}{ }^{3-}, \mathrm{SiO}_{3}{ }^{-}, \mathrm{NO}_{2}{ }^{-}, \mathrm{NO}_{3}{ }^{-}$, and $\mathrm{SO}_{4}{ }^{2-}$ concentrations were considerably reduced. 
Table 5. The effect of treatments on the physicochemical parameters in El-Umoum drain water during spring 2014

\begin{tabular}{|c|c|c|c|c|c|c|}
\hline El-Umoum & $\underset{\mathrm{mgO}_{2} / \mathbf{l}}{\mathrm{OOM}^{2}}$ & $\mathrm{PO}^{\mathrm{PM}^{3-}}$ & $\underset{\mu \mathrm{MiO}}{\mathrm{SiO}_{3}^{-}}$ & $\mathrm{NO}_{2}^{-} \boldsymbol{\mu M}$ & $\mathrm{NO}^{\mathrm{NM}^{-}}$ & $\mathrm{SO}_{4}{ }^{2-} \mathrm{g} / \mathrm{l}$ \\
\hline $\begin{array}{l}\text { I. El-Umoum } \\
\text { agricultural } \\
\text { waste water }\end{array}$ & 37.68 & 10.95 & 88.3 & 33.05 & 67.13 & 2.45 \\
\hline $\begin{array}{l}\text { II. El-Umoum } \\
\text { agricultural } \\
\text { waste water + } \\
\text { Alum + aeration }\end{array}$ & 18.56 & 9.00 & 45.82 & 20.18 & 52.33 & 1.64 \\
\hline $\begin{array}{l}\text { III. El-Umoum } \\
\text { agricultural } \\
\text { waste water + } \\
\text { Alum + aeration } \\
+ \text { Ceratophyllum }\end{array}$ & 15.04 & 1.95 & 29.16 & 0.15 & 17.65 & 1.7 \\
\hline $\begin{array}{l}\text { IV. El-Umoum } \\
\text { agricultural } \\
\text { waste water + } \\
\text { Piper nigrum+ } \\
\text { alum }+ \text { aeration }\end{array}$ & 18.23 & 2.75 & 40.82 & 5.83 & 0.92 & 1.43 \\
\hline $\begin{array}{l}\text { V. El-Umoum } \\
\text { agricultural } \\
\text { waste water + } \\
\text { Piper nigrum + } \\
\text { alum + aeration } \\
+ \text { Ceratophyllum }\end{array}$ & 14.72 & 1.2 & 16.66 & 1.5 & 0.07 & 1.52 \\
\hline $\begin{array}{l}\text { VI. EI-Umoum } \\
\text { agricultural } \\
\text { waste water + } \\
\text { Ginger + alum + } \\
\text { aeration }\end{array}$ & 11.52 & 1.9 & 37.49 & 14.08 & 12.44 & 1.38 \\
\hline $\begin{array}{l}\text { VII. El-Umoum } \\
\text { agricultural } \\
\text { waste water + } \\
\text { Ginger + alum + } \\
\text { aeration + } \\
\text { Ceratophyllum }\end{array}$ & 10.24 & 1.7 & 14.16 & 0.1 & 5.24 & 1.56 \\
\hline $\begin{array}{l}\text { VIII. El-Umoum } \\
\text { agricultural } \\
\text { waste water + } \\
\text { Yeast }+ \text { alum + } \\
\text { aeration }\end{array}$ & 18.97 & 1.35 & 42.07 & 7.95 & 0.07 & 1.35 \\
\hline $\begin{array}{l}\text { IX. EI-Umoum } \\
\text { agricultural } \\
\text { waste water + } \\
\text { Yeast }+ \text { alum + } \\
\text { aeration }+ \\
\text { Ceratophyllum }\end{array}$ & 7.68 & 1.2 & 41.06 & 0.18 & 0.04 & 0.78 \\
\hline
\end{tabular}




\section{Macrothink}

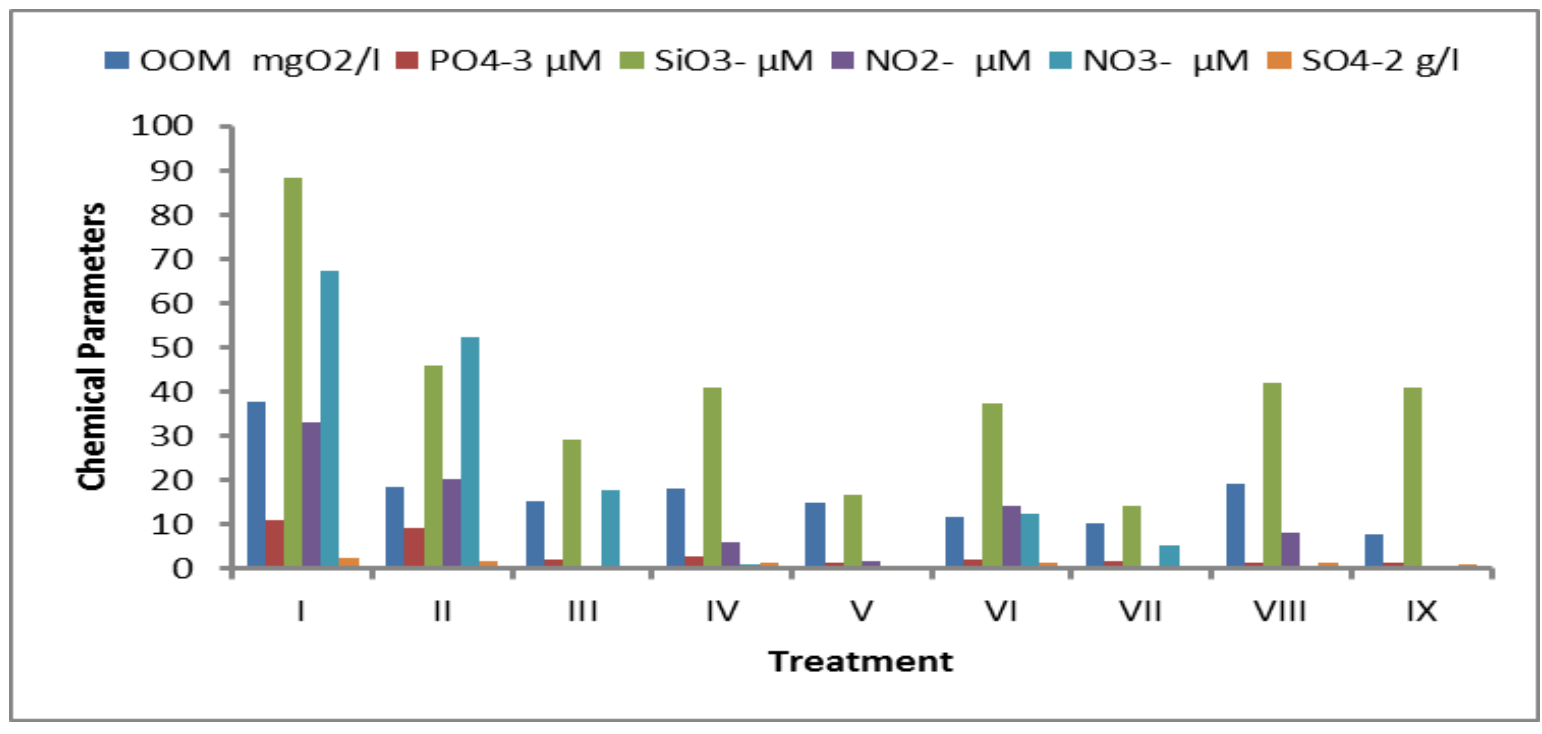

Figure 6. The effect of different treatments on the chemical parameters of El-Umoum drain water during spring 2014

Generally, yeast and the macrophyte Ceratophylum demersum with Alum + Aeration showed noticeable decrease in $\mathrm{OOM}, \mathrm{PO}_{4}{ }^{3-}, \mathrm{SiO}_{3}{ }^{-}, \mathrm{NO}_{2}{ }^{-}, \mathrm{NO}_{3}{ }^{-}$and $\mathrm{SO}_{4}{ }^{2-}$ concentrations indicating that these treatments were the best for agricultural wastewater at El-Umoum drain during this study.

3.3.2 The Effect of Different Treatments on the Trace Metals Concentrations of El-Umoum Agricultural Drain

All treatments succeeded to reduce the concentrations of the trace metals concentrations ( $\mathrm{Zn}$, $\mathrm{Pb}, \mathrm{Fe}$, and $\mathrm{Cu}$ ) beginning from using Alum + Aeration till adding the piper nigrum, dry ginger, and yeast for treatment, in addition to the freshwater submerged macrophyte Ceratophyllum demersum.

The highest reduction in trace metals concentrations was observed with the treatment by Alum + Aeration+ Yeast+ Ceratophyllum (Table 6 and Fig. 7). The reduction of trace metals was observed in all media in the presence of the submerged macrophyte Ceratophyllum demersum. The treatment type most successful in reducing trace metals concentrations of El-Umoum agricultural drain was by using Yeast. 


\section{Macrothink}

Table 6. The effect of treatments on trace metals concentrations $(\mu \mathrm{M})$ of El-Umoum drain water during spring 2014

\begin{tabular}{l|c|c|c|c}
\hline El-Umoum & \multicolumn{1}{|l|}{$\mathbf{P b}$} & $\mathbf{F e}$ & $\mathbf{C u}$ \\
\hline (1) El-Umoum agricultural drain & 19.8 & 27 & 168.9 & 18.3 \\
\hline (II) El-Umoum agricultural drain + Alum + Aeration & 15.7 & 19.5 & 114.1 & 11.6 \\
\hline $\begin{array}{l}\text { (IV) El-Umoum agricultural drain + Alum + Aeration + } \\
\text { Piper }\end{array}$ & 13.1 & 12.9 & 86.4 & 9 \\
\hline $\begin{array}{l}\text { (V) El-Umoum agricultural drain + Alum + Aeration + } \\
\text { Piper + Ceratophyllum }\end{array}$ & 11.2 & 9.5 & 80.3 & 6.9 \\
\hline $\begin{array}{l}\text { (VI) El-Umoum agricultural drain + Alum + Aeration + } \\
\text { Ginger }\end{array}$ & 11.8 & 14.3 & 100.9 & 7.4 \\
\hline $\begin{array}{l}\text { (VII) El-Umoum agricultural drain + Alum + Aeration } \\
\text { + Ginger + Ceratophyllum }\end{array}$ & 8.7 & 10.1 & 89.2 & 5.8 \\
\hline $\begin{array}{l}\text { (VIII) El-Umoum agricultural drain + Alum + Aeration } \\
\text { + Yeast }\end{array}$ & 8.3 & 4.9 & 68.5 & 2.6 \\
\hline $\begin{array}{l}\text { (IX) El-Umoum agricultural drain + Alum + Aeration + } \\
\text { Yeast + Ceratophyllum }\end{array}$ & 7.5 & 2.3 & 59.1 & 1.9 \\
\hline
\end{tabular}

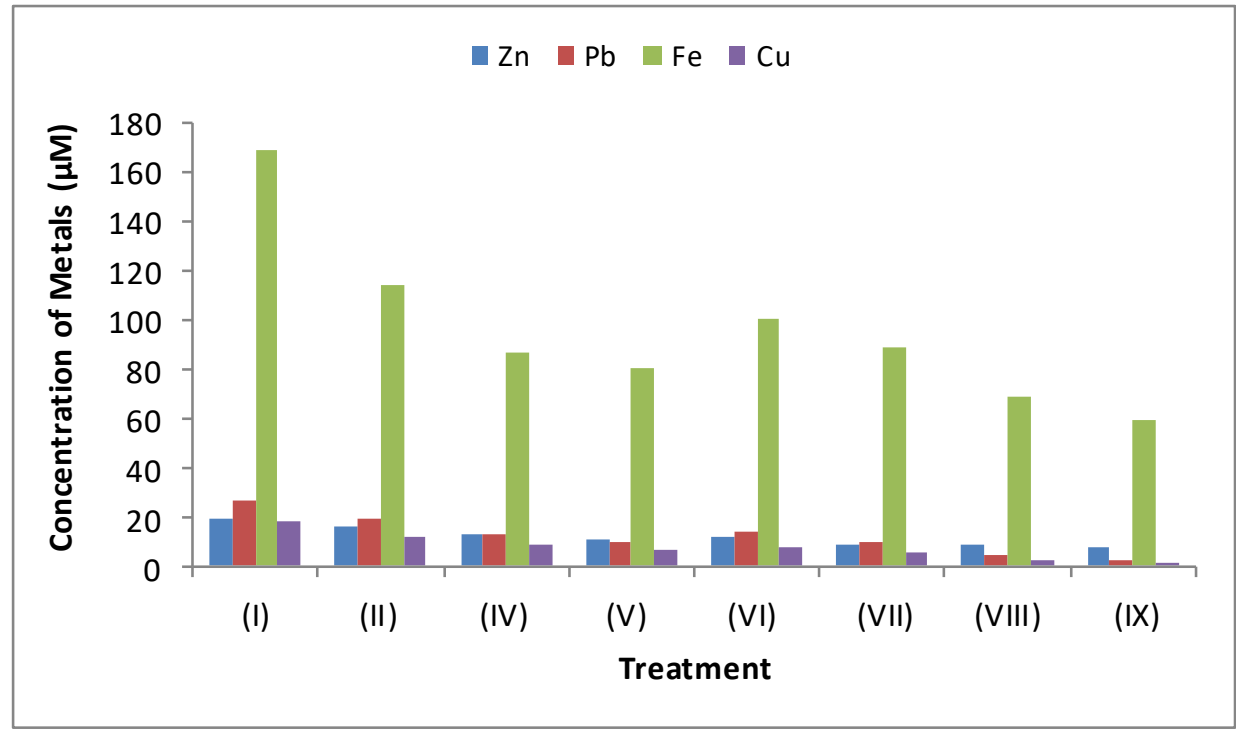

Figure 7. The effect of different treatments on the trace metals concentrations of El-Umoum agricultural drain water during spring 2014

Generally, the results obtained for trace metals treatment for agricultural waste water were similar to that of the raw water treatment by using Alum + Aeration + Yeast + Ceratophyllum .

\section{Discussion}

\subsection{Percentage Reduction of the OOM, Nutrients and Sulphate Concentrations}

Reduction percentage of OOM sustained high performance, recording 75.6\%, 50.74\%, and $28.2 \%$ for raw wastewater from El-Qalaa, El-Umoum drains, and Nubareya canal, 
respectively, when treated with alum and aeration (Table 7). When using combined physical, chemical, and biological treatments, OOM was profoundly reduced, and recorded between $83.5 \%$ using Ceratophyllum beside (alum + aeration) and $92.6 \%$ reduction in ginger treatment media beside Ceratophyllum + (alum + aeration) using sewage water from El-Qalaa. OOM from Umoum and Nubareya drains reduction percentages were $79.62 \%$ and $92.06 \%$, respectively, recorded when treated with combined yeast $+($ alum + aeration $)+$ Ceratophyllum.

The least reduction percentage for $\mathrm{PO}_{4}{ }^{3-}$ was in treatment with alum + aeration only $(3.0 \%)$ for El-Qalaa sewage water, and it increased with treatments using combination of physical, chemical, and biological media, recording the highest value $81.4 \%$ of reduction in combined yeast and (alum + aeration). Concerning El-Umoum agricultural wastewater, $\mathrm{PO}_{4}{ }^{3-}$ was slightly reduced with alum + aeration treatment (17.81\%), while high reduction percentages were sustained in combined treatments, recording a maximum of $89.04 \%$ in piper nigrum and yeast combined with alum + aeration + Ceratophyllum treatment media. For Nubareya raw drinking water, alum + aeration reduced $\mathrm{PO}_{4}{ }^{3-}$ by $77.41 \%$, which is considerably high compared with that of El-Qalaa sewage water. On the other hand, combined treatments exhibited high reduction performance, particularly in piper nigrum, ginger, and yeast media, the highest of which was $97.41 \%$ in yeast + alum + aeration treatment, whether accompanied by the macrophyte Ceratophyllum or not.

$\mathrm{SiO}_{3}{ }^{-}$was highly reduced from El-Qalaa sewage water in ginger combined treatment media $(82.8 \%$ and $80.9 \%)$, followed by yeast combined treatment media $(73.5 \%$ and $68.4 \%)$. In El-Umoum wastewater, $\mathrm{SiO}_{3}{ }^{-}$was reduced considerably in piper nigrum and ginger combined treatment media recording $81.1 \%$ and $83.96 \%$, respectively, but decreasing reduction capacity was obvious in other treatments. For Nubareya raw drinking water, $\mathrm{SiO}_{3}{ }^{-}$was highly reduced in ginger followed by yeast combined treatment media, but to less extent compared with the results obtained in El-Qalaa sewage water's case (Table 7).

About $50 \%$ of $\mathrm{NO}_{2}{ }^{-}$in El-Qalaa wastewater was reduced in alum + aeration treatment media, and was further reduced in other combined treatments media -ginger + alum + aeration + Ceratophyllum (93.3\%)- but to less extent in other treatments. A $38.9 \%$ reduction was noticed for treatment by alum + aeration in El-Umoum drain. The highest removal percentage was observed to be between 99.5 and 99.7 in combined treatments yeast + (alum + aeration) + Ceratophyllum, followed by alum + aeration + Ceratophyllum, then ginger + alum + aeration + Ceratophyllum. $\mathrm{NO}_{2}{ }^{-}$concentration in Nubareya raw drinking water was low $(0.08$ $\mu \mathrm{M}$ ) (Table 3), but about 50\% was reduced in combined treatment (piper + alum + aeration + Ceratophyllum).

From $5.33 \mu \mathrm{M} \mathrm{NO}_{3}{ }^{-}$initial concentration in El-Qalaa Drain water (Table 1), slight reduction ranging from $12.4 \%$ to $20.6 \%$ was recorded in treatments with combined piper nigrum + alum + aeration + Ceratophyllum and piper nigrum + alum + aeration, respectively. Maximum reduction was found to be $96.3 \%$, and to less extent $95.5 \%$, and $61.7 \%$ in combined treatments with yeast + alum + aeration, followed by yeast + alum + aeration + Ceratophyllum, then ginger + alum + aeration + Ceratophyllum, respectively. Reduction 
percentage of $\mathrm{NO}_{3}{ }^{-}$in El-Umoum agricultural drain fluctuated between $73.7 \%$ for treatment by alum + aeration + Ceratophyllum, and $99.9 \%$ in combined treatments by piper nigrum + alum + aeration + Ceratophyllum and for yeast treatment with alum + aeration with/without Ceratophyllum. In Nubareya raw water, the nitrate removal percentage differed from $6.39 \%$ in treatment using alum + aeration + Ceratophyllum and $37.6 \%$ in treatment by yeast + alum + aeration. Sulphate removal percentage was $32.4 \%$ in treatment by alum + aeration for sewage seawater of El-Qalaa drain. This removal percentage value increased to $62.2 \%$ followed by $62.5 \%$ with yeast treatment combined with alum + aeration, followed by yeast + alum + aeration + Ceratophyllum, respectively. The lowest sulphate removal percentage in El-Umoum drain and Nubareya raw water were $30.61 \%$ and $31.14 \%$, respectively, for treatment by alum + aeration + Ceratophyllum, while the highest sulphate removal percentage for both El-Umoum drain and Nubareya raw water was $68.16 \%$ and $55.43 \%$, respectively, for the treatment by yeast + alum + aeration + Ceratophyllum . 
Table 7. Percentage removal of the OOM, nutrients and sulphate concentrations after different treatments for Mariout Lake drains water

\begin{tabular}{|c|c|c|c|c|c|c|}
\hline Drain & $\begin{array}{l}\text { OOM \% } \\
\text { Removal }\end{array}$ & $\begin{array}{l}\mathrm{PO}_{4}{ }^{3-} \quad \% \\
\text { Removal }\end{array}$ & $\begin{array}{l}\mathrm{SiO}_{3}{ }^{-} \% \\
\text { Removal }\end{array}$ & $\begin{array}{l}\text { NO } \quad 2 \% \\
\text { Removal }\end{array}$ & $\begin{array}{l}\mathrm{NO}_{3}^{-} \% \\
\text { Removal }\end{array}$ & $\begin{array}{l}\mathrm{SO}_{4}{ }^{2-} \% \\
\text { Removal }\end{array}$ \\
\hline $\begin{array}{l}\text { II. El-Qalaa sewage + Alum + } \\
\text { aeration }\end{array}$ & 75.6 & 3.00 & 28.8 & 49.8 & 20.3 & 32.4 \\
\hline $\begin{array}{l}\text { II. El-Umoum agricultural waste } \\
\text { water + Alum + aeration }\end{array}$ & 50.74 & 17.81 & 48.1 & 38.9 & 22.1 & 33.06 \\
\hline $\begin{array}{l}\text { II. Nubareya raw water + Alum + } \\
\text { aeration }\end{array}$ & 28.2 & 77.41 & 10.1 & 0.0 & 30.5 & 36.3 \\
\hline $\begin{array}{l}\text { III. El-Qalaa sewage + Alum + } \\
\text { aeration + Ceratophyllum }\end{array}$ & 83.5 & 37.2 & 66.5 & 72.4 & 20.4 & 33 \\
\hline $\begin{array}{l}\text { IV. EI-Qalaa sewage + Alum + } \\
\text { aeration + Piper nigrum }\end{array}$ & 85.3 & 50.9 & 29.7 & 80 & 20.6 & 32.7 \\
\hline $\begin{array}{l}\text { V. El-Qalaa sewage + Piper } \\
\text { nigrum }+ \text { alum }+ \text { aeration }+ \\
\text { Ceratophyllum }\end{array}$ & 89.9 & 57.1 & 52.5 & 83.1 & 12.4 & 33.8 \\
\hline $\begin{array}{l}\text { VI. El-Qalaa sewage + Ginger + } \\
\text { alum + aeration }\end{array}$ & 90.8 & 80.5 & 82.8 & 69.8 & 20.3 & 33.8 \\
\hline $\begin{array}{l}\text { VII. EI-Qalaa sewage + Ginger + } \\
\text { alum + aeration + Ceratophyllum }\end{array}$ & 92.6 & 76.2 & 80.9 & 93.3 & 61.7 & 39.3 \\
\hline $\begin{array}{l}\text { VIII. EI-Qalaa sewage + Yeast + } \\
\text { alum + aeration }\end{array}$ & 85.3 & 81.4 & 68.4 & 58.7 & 96.3 & 62.2 \\
\hline $\begin{array}{l}\text { IX. El-Qalaa sewage }+ \text { alum + } \\
\text { aeration + Yeast }+ \text { Ceratophyllum }\end{array}$ & 88 & 79.3 & 73.5 & 80.9 & 95.5 & 62.5 \\
\hline $\begin{array}{l}\text { III. El-Umoum agricultural waste } \\
\text { water }+ \text { Alum }+ \text { aeration }+ \\
\text { Ceratophyllum }\end{array}$ & 60.1 & 82.19 & 67.0 & 99.6 & 73.7 & 30.61 \\
\hline $\begin{array}{l}\text { IV. El-Umoum agricultural waste } \\
\text { water + Piper nigrum + alum + } \\
\text { aeration }\end{array}$ & 51.6 & 74.89 & 53.8 & 82.4 & 98.6 & 41.63 \\
\hline $\begin{array}{l}\text { V. El-Umoum agricultural waste } \\
\text { water }+ \text { Piper nigrum }+ \text { alum }+ \\
\text { aeration }+ \text { Ceratophyllum }\end{array}$ & 60.9 & 89.04 & 81.1 & 95.5 & 99.9 & 37.96 \\
\hline $\begin{array}{l}\text { VI. El-Umoum agricultural waste } \\
\text { water + Ginger + alum + aeration }\end{array}$ & 69.4 & 82.65 & 57.5 & 57.4 & 96.4 & 43.67 \\
\hline $\begin{array}{l}\text { VII. El-Umoum agricultural } \\
\text { waste water + Ginger + alum + } \\
\text { aeration }+ \text { Ceratophyllum }\end{array}$ & 72.8 & 74.48 & 83.96 & 99.7 & 92.2 & 36.33 \\
\hline $\begin{array}{l}\text { VIII. El-Umoum agricultural } \\
\text { waste water + Yeast + alum + } \\
\text { aeration }\end{array}$ & 49.7 & 87.76 & 52.4 & 76.0 & 99.9 & 44.9 \\
\hline $\begin{array}{l}\text { IX. El-Umoum agricultural waste } \\
\text { water + Yeast + alum + aeration + } \\
\text { Ceratophyllum }\end{array}$ & 79.62 & 89.04 & 53.5 & 99.5 & 99.9 & 68.16 \\
\hline $\begin{array}{l}\text { III. Nubareya raw water + Alum } \\
+ \text { aeration + Ceratophyllum }\end{array}$ & 32.4 & 76.74 & 4.2 & 0.00 & 6.39 & 31.14 \\
\hline $\begin{array}{l}\text { IV. Nubareya raw water + Piper } \\
\text { nigrum + (alum + aeration) }\end{array}$ & 28.5 & 81.11 & 10.6 & 37.5 & 13.8 & 35.14 \\
\hline $\begin{array}{l}\text { V. Nubareya raw water }+ \text { Piper } \\
\text { nigrum }+ \text { (alum }+ \text { aeration) }+ \\
\text { Ceratophyllum }\end{array}$ & 29.5 & 83.07 & 37.9 & 50.0 & 11.1 & 28.3 \\
\hline $\begin{array}{l}\text { VI. Nubareya raw water + Ginger } \\
+(\text { alum + aeration }) \\
\end{array}$ & 43.9 & 93.7 & 67.7 & 37.5 & 19.1 & 36.57 \\
\hline $\begin{array}{l}\text { VII. Nubareya raw water + } \\
\text { Ginger }+(\text { alum }+ \text { aeration })+ \\
\text { Ceratophyllum }\end{array}$ & 66.7 & 94.44 & 66.8 & 0.00 & 9.4 & 37.14 \\
\hline $\begin{array}{l}\text { VIII. Nubareya raw water + Yeast } \\
+(\text { alum + aeration })\end{array}$ & 89.5 & 97.41 & 50.1 & 37.5 & 37.6 & 44.57 \\
\hline 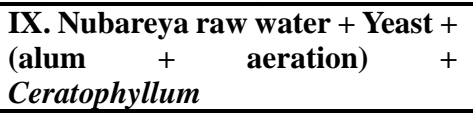 & 92.06 & 96.96 & 50.3 & 37.5 & 34.6 & 55.43 \\
\hline
\end{tabular}




\section{Macrothink}

4.2 Reduction Percentage of the Trace Metals after Different Treatments for Mariout Lake Drains

The lowest percentage of metals removal for El-Qalaa sewage drain, El-Umoum agricultural drain, and Nubareya raw water canal was recorded for the treatment using alum + aeration only (Table 8). For El-Qalaa sewage drain, the highest $\mathrm{Pb}, \mathrm{Fe}$, and $\mathrm{Cu}$ removals $(91.71 \%$, $60.48 \%$ and $93.13 \%$ ) respectively were found with the treatment with yeast + alum + aeration + Ceratophyllum, while the highest $\mathrm{Zn}$ removal (62.65\%) was observed with the treatment with ginger + alum + aeration + Ceratophyllum, followed by the treatment with yeast + alum + aeration + Ceratophyllum (54.47\%). Regarding El-Umoum agricultural drain, it was observed that all metals' removal percentages $(62.12 \%, 91.48 \%, 65.01 \%$, and $89.62 \%)$, respectively for $\mathrm{Zn}, \mathrm{Pb}, \mathrm{Fe}$, and $\mathrm{Cu}$ were recorded for the treatment with yeast + alum + aeration + Ceratophyllum. For Nubareya raw water, the highest metals' $(\mathrm{Zn}, \mathrm{Pb}, \mathrm{Fe}$, and $\mathrm{Cu})$ removals $(65.96 \%, 85.62 \%, 85.41 \%$, and $100 \%)$ respectively were for the treatment with yeast + alum + aeration + Ceratophyllum.

It was generally noticed that the best treatment for metals' removal was with (yeast + alum + aeration + Ceratophyllum), and it could be applied for different sources of polluted waters like sewage water (El-Qalaa drain), agricultural water (El-Umoum drain), and raw drinking water (Nubareya Canal). 
Table 8. Percentage removal of the trace metals after different treatments for Mariout Lake drains

\begin{tabular}{|c|c|c|c|c|}
\hline Drain waters with different treatments & $\begin{array}{c}\text { Zn \% } \\
\text { Removal }\end{array}$ & $\begin{array}{c}\text { Pb \% } \\
\text { Removal }\end{array}$ & $\begin{array}{c}\text { Fe \% } \\
\text { Removal }\end{array}$ & $\begin{array}{c}\text { Cu \% } \\
\text { Removal }\end{array}$ \\
\hline (II) EI-Qalaa sewage +Alum + Aeration & 30.74 & 36.29 & 28.39 & 13.75 \\
\hline $\begin{array}{l}\text { (IV) El-Qalaa sewage }+ \text { Alum }+ \text { Aeration }+ \\
\text { Piper nigrum }\end{array}$ & 37.74 & 45.43 & 42.02 & 36.25 \\
\hline $\begin{array}{l}\text { (V) El-Qalaa sewage +Alum + Aeration + Piper } \\
\text { nigrum + Ceratophyllum }\end{array}$ & 43.19 & 62.29 & 53.69 & 46.88 \\
\hline $\begin{array}{l}\text { (VI) El-Qalaa sewage +Alum }+ \text { Aeration }+ \\
\text { Ginger }\end{array}$ & 54.09 & 57.71 & 29.94 & 58.75 \\
\hline $\begin{array}{l}\text { (VII) El-Qalaa sewage +Alum + Aeration + } \\
\text { Ginger }+ \text { Ceratophyllum }\end{array}$ & 62.65 & 70.57 & 38.57 & 70 \\
\hline $\begin{array}{l}\text { (VIII) El-Qalaa sewage }+ \text { Alum }+ \text { Aeration }+ \\
\text { Yeast }\end{array}$ & 43.19 & 84 & 52.26 & 90.63 \\
\hline $\begin{array}{l}\text { (IX) EI-Qalaa sewage }+ \text { Alum }+ \text { Aeration }+ \\
\text { Yeast }+ \text { Ceratophyllum }\end{array}$ & 54.47 & 91.71 & 60.18 & 93.13 \\
\hline $\begin{array}{l}\text { (II) El-Umoum agricultural drain }+ \text { Alum }+ \\
\text { Aeration }\end{array}$ & 20.7 & 27.78 & 32.45 & 36.61 \\
\hline $\begin{array}{l}\text { (IV) El-Umoum agricultural drain + Alum + } \\
\text { Aeration + Piper nigrum }\end{array}$ & 33.84 & 52.22 & 48.85 & 50.82 \\
\hline $\begin{array}{l}\text { (V) El-Umoum agricultural drain }+ \text { Alum }+ \\
\text { Aeration + Piper nigrum }+ \text { Ceratophyllum }\end{array}$ & 43.43 & 64.48 & 52.46 & 62.3 \\
\hline $\begin{array}{l}\text { (VI) El-Umoum agricultural drain + Alum + } \\
\text { Aeration + Ginger }\end{array}$ & 40.4 & 47.04 & 40.26 & 59.56 \\
\hline $\begin{array}{l}\text { (VII) El-Umoum agricultural drain + Alum + } \\
\text { Aeration + Ginger + Ceratophyllum }\end{array}$ & 56.06 & 62.59 & 47.19 & 68.31 \\
\hline $\begin{array}{l}\text { (VIII) El-Umoum agricultural drain + Alum + } \\
\text { Aeration + Yeast }\end{array}$ & 58.08 & 81.85 & 59.44 & 85.79 \\
\hline $\begin{array}{l}\text { (IX) El-Umoum agricultural drain + Alum + } \\
\text { Aeration + Yeast + Ceratophyllum }\end{array}$ & 62.12 & 91.48 & 65.01 & 89.62 \\
\hline (II) Nubareya raw water + Alum + Aeration & 26.6 & 11.64 & 29.48 & $\mathbf{3 7 . 3 7}$ \\
\hline $\begin{array}{l}\text { (IV) Nubareya raw water + Alum + Aeration } \\
+ \text { Piper nigrum }\end{array}$ & 31.91 & 42.47 & 82.52 & 46.46 \\
\hline $\begin{array}{l}\text { (V) Nubareya raw water + Alum + Aeration + } \\
\text { piper nigrum + Ceratophyllum }\end{array}$ & 44.68 & 67.12 & 85.11 & 60.6 \\
\hline $\begin{array}{l}\text { (VI) Nubareya raw water + Alum + Aeration + } \\
\text { Ginger }\end{array}$ & 38.62 & 52.74 & 64.13 & $\mathbf{5 7 . 5 7}$ \\
\hline $\begin{array}{l}\text { (VII) Nubareya raw water + Alum + Aeration } \\
\text { +Ginger+ Ceratophyllum }\end{array}$ & 52.66 & 67.81 & 67.63 & 71.71 \\
\hline $\begin{array}{l}\text { (VIII) Nubareya raw water + Alum + Aeration } \\
\text { +Yeast }\end{array}$ & 56.38 & 76.71 & 81.76 & 100 \\
\hline $\begin{array}{l}\text { (IX) Nubareya raw water + Alum + Aeration+ } \\
\text { Yeast }+ \text { Ceratophyllum }\end{array}$ & 65.96 & 85.62 & 85.41 & 100 \\
\hline
\end{tabular}

\section{Conclusions}

The physicochemical parameters are considered the most important principles in the identification of the nature, quality, and type of water (fresh, brackish, saline) for any aquatic ecosystem.

The results of the physicochemical parameters present in Tables 1, 3, and 5 reveal that the best material for treatment in El-Qalaa sewage drain was with (Alum + Aeration + ginger + Ceratophylum demersum). This treatment reduced the parameters causing pollution (OOM, $\mathrm{PO}_{4}{ }^{3-}$, and $\mathrm{NO}_{2}{ }^{-}$) with up to $92 \%, 76.2 \%$, and $93.3 \%$ reduction for El-Qalaa drain. These 
results indicate that good water quality was obtained after treatment, and if this treated water reaches the Lake, it would not pollute the Lake's water.

The most preferable treatment for the raw drinking water of Nubareya canal was by using Alum + Aeration + yeast + Ceratophylum demersum. For the El-Umoum agricultural wastewater, the best treatment was the same as that of the raw drinking water of Nubareya canal (Alum + Aeration + yeast $+C$. demersum $)$.

With regards the four trace metals' treatments, the best treatment in all cases was by using, Alum + Aeration + Yeast + Ceratophylum demersum except for $\mathrm{Zn}$, in El-Qalaa sewage water, which had to be treated by using Alum + Aeration + Ginger + Ceratophylum demersum, followed by Alum + Aeration + Yeast + Ceratophylum demersum .

Treating the different types of waste water should be taken into consideration by the decision makers before the waste water reaches Mariout Lake, so as to improve the lake's water quality, and therefore increase its fish productivity, and for good quality water to reach the Mediterranean Sea through El-Mex Bay.

The different types of treatments used in this study are of low cost and environmentally safe.

\section{Acknowledgement}

The authors are grateful to the National Institute of Oceanography and Fisheries for the fund, help, and support to complete this work through the project titled: "Development of the Northern Lakes and Increasing their Productivity (Case Study, Mariout Lake), 2014".

\section{References}

Abdel-Shafy, H. I., \& Raouf, O. A. (2002). Water Issue in Egypt: Resources, Pollution and Protection Endeavors; Review Article, CEJOEM, 8(1), 3-21.

Akar, S. T., Yetimoglue, Y., \& Gedikbey, T. (2009). Removal of chromium (VI) ions from aqueous solutions by using Turkish montmorillonite clay: effect of activation and modification. Desalination, 244, 97-108. https://doi.org/10.1016/j.desal.2008.04.040

APHA standard methods for the examination of water and wastewater (1995); American Public Health Association, 12th edition, New York. 769p.

Berkowitz, J., Anderson, M. A., \& Graham, R. C. (2006). Laboratory investigation of aluminum solubility and solid-phase properties following alum treatment of lake waters. Water Research, 39(16), 3918-28. https://doi.org/10.1016/j.watres.2005.06.025

Bhatti, M. T., \& Latif, M. (2011). Assessment of water quality of a river using an indexing approach during the low-flow season. Irrigation Drainage, 60, 103-114. https://doi.org/10.1002/ird.549

Chang, P., Jun, C., Ke, W., Zhongkai Z., \& Tingting C. (2018) Heavy Metal Contaminated Soil Imitation Biological Treatment Overview. IOP Conference Series: Materials Science and Engineering. https://doi.org/10.1088/1757-899X/301/1/012113 
Daoud, J. R., Amin, A. M., \& Abd El-Khalek, M. M. (1999). Residual analysis of some heavy metals in water and Oreochromis niloticus fish from polluted areas. Journal of Veterinary Medicine, 74, 351-365. http://far-malr.gov.eg/en/edika.php

Dubey, S. P., \& Gopal, K. (2007). Adsorption of chromium (VI) on low cost adsorbents derived from agricultural waste material: a comparative study. Journal of Hazardous Materials, 145(3), 465-70. https://doi.org/10.1016/j.jhazmat.2006.11.041

El Zokm, G. M., Tadros, H. R. Z., Okbah, M. A., \& Ibrahim, G. H. (2018). Eutrophication assessment using TRIX and Carlson's indices in Lake Mariout Water, Egypt. Egyptian Journal of Aquatic Biology \& Fisheries. Zoology Department, Faculty of Science, Ain Shams University, Cairo, Egypt. 22(5), 331-349. ISSN 1110-6131

https://doi.org/10.21608/ejabf.2018.23918

FAO. (1975). Manual of methods in aquatic environment research. FAO Fish. Tech. Paper No. 137, $238 \mathrm{pp}$.

Foroughi, M., Najafi, P., Toghiani, A., \& Honarjoo, N. (2010). Analysis of pollution removal from wastewater by Ceratophyllum demersum, African Journal of Biotechnology, 9, 2125-2128. http://www.academicjournals.org/AJB

Grady, C. P. L., Daigger, G. T., \& Lim, H. C. (1999). Biological Wastewater Treatment. ${ }^{\text {nd }}$ Ed. Marcel Dekker, New York. (Chapters 10, 11, 19 \& 20)

Gray, N. F. (1989). Biology of Wastewater Treatment. Oxford Science Publications, Oxford. (Chapters 2 \& 4).

Jiang, B., Xing, Y., Zhang, B. G., Cai, R. Q., Zhang, D. Y., \& Sun, G. D. (2018). Effective phytoremediation of low-level heavy metals by native macrophytes in a vanadium mining area, China. Environmental Science and Pollution Research, 25, 31272-31282. https://doi.org/10.1007/s11356-018-3069-9

Juliana, C., Affonso, C. G. Jr., Coelho, G. F., \& Douglas, C. D. (2016). Adsorption of Metallic Ions $\mathrm{Cd} 2+, \mathrm{Pb} 2+$, and $\mathrm{Cr} 3+$ from Water Samples Using Brazil Nut Shell as a Low-Cost Biosorbent: Mishra/Smart. In book: Smart Materials for Waste Water Applications, pp.311-334. https://doi.org/10.1002/9781119041214.ch12

Karla, M. H. M., Onofre, M. A., María, T. C. B., Francisco, J. A. T., \& Evelia, A. F. (2013). Metallic Biosorption Using Yeasts in Continuous Systems. International Journal of Photoenergy, Article ID 578729, 4 pages. https://doi.org/10.1155/2013/578729

Lai, C. H., Yung, C. C., \& Hsuan, H. Y. (2015). Assessing the interaction effects of coagulation pretreatment and membrane material on UF fouling control using HPSEC combined with peak-fitting. Journal of Membrane Science. 474, 207-214. https://doi.org/10.1016/j.memsci.2014.09.052

Lynette, M. M. B., John, W., \& Konda, R. R. (2007) Soil Biogeochemical Characteristics Influenced by Alum Application in a Municipal Wastewater Treatment Wetland. Journal of Environmental Quality 36(6), 1904-1913. https://doi.org/10.2134/jeq2007.0159 
Mateo, M. A. (2009). Lake Mariut: An ecological assessment. WADI project water demand integration; INCO-CT-2005-015226.

Nguyen, C. T., \& Ronald, E. S. (1973). Biological Treatment of Wastewater by Yeasts. Journal of Water Pollution Control Federation, 45(4), 674-680. PMID: 4572521

Orumwense, F. F. O. (1996). Removal of lead from water by adsorption on a kaolinitic clay. Journal of Chemical Technology and Biotechnology. 65, 363-369.

https://doi.org/10.1002/(SICI)1097-4660(199604)65:4<363::AID-JCTB435>3.3.CO;2-V

Rehm, H. J., \& Reed, G. (1986). Biotechnology. Vol. 8 Microbial Degradations. VCH, Weinheim. (Chapters $2 \& 3$ )

Remigius, C., Hanneliese, M., \& Chlodwig, F. (2003). Monitoring of metallic micronutrients and heavy metals in herbs, spices and medicinal plants from Austria. European Food Research and Technology 216(5), 407-411. https://doi.org/ 10.1007/s00217-003-0675-6

Rossum, J. R., \& Villarruz, P. A. (1961); Suggested methods for turbidimetric determination of sulphate in seawater. JAWWA, 53-873. https://doi.org/10.1002/j.1551-8833.1961.tb00723.x

Saad, A. S., Massoud, R. A., \& Ghorab, M. A. (2017). Assessment of the Physicochemical Characteristics and Water Quality Analysis of Mariout Lake, Southern of Alexandria, Egypt. J Environ Anal Toxicology, 7(1), 1-19. https://www.researchgate.net/publication/312585833.

Takashi, W., Noriatsu, O., Kazuhiro, I., \& Tsutomu, F. (2008). Breeding of wastewater treatment yeasts that accumulate high concentrates of phosphorus. Applied Microbiology and Biotechnology, 80(2), 331-338. https://doi.org/10.1007/s00253-008-1529-8

Welch, E. B., \& Schrieve, G. D. (1994). Alum treatment effectiveness and longevity in shallow lakes. Hydrobiologia, 275-276(1), 423-431. https://doi.org/10.1007/BF00026731

Yan Wang, L. Q., \& Mengfei, H. (2018). Application of yeast in the wastewater treatment. E3S Web of Conferences 53, 04025. https://doi.org/10.1051/e3sconf/20185304025

Yang, M., \& Zheng, S. (2014). Pollutant removal-oriented yeast biomass production from high-organic-strength industrial wastewater: A review. Biomass and Bioenergy, 64, 356-362. https://doi.org/10.1016/j.biombioe.2014.03.020

Zhou, H., \& Smith, D. W. (2002). Advanced Technologies in Water and Wastewater Treatment, Journal of Environmental Engineering Science, 1, 247-264. https://doi.org/10.1139/s02-020

\section{Copyrights}

Copyright for this article is retained by the author(s), with first publication rights granted to the journal.

This is an open-access article distributed under the terms and conditions of the Creative Commons Attribution license (http://creativecommons.org/licenses/by/4.0/) 